\title{
PEMANFAATAN ISI RUMEN SAPI \\ DI RUMAH POTONG HEWAN PEGIRIAN SEBAGAI BIOGAS
}

Andy Susilo Putro Mariyono, Darjati, Deddy Adam

Jurusan Kesehatan Lingkungan Poltekkes Kemenkes Surabaya

Email : andy.susilo1109@gmail.com

\begin{abstract}
ABSTRAK
Pengolahan limbah cairan isi rumen dan kotoran sapi dapat dilakukan dengan cara fermentasi anaerob (tanpa oksigen), dan merupakan salah satu alternatif untuk mengurangi pencemaran lingkungan. Dalam proses tersebut bahan organik akan didegrasi oleh mikroba yang dapat menghasilkan biogas. Penelitian ini bertujuan untuk mengetahui perbedaan kadar gas metan $\left(\mathrm{CH}_{4}\right)$ yang dihasilkan dari proses biogas dengan 3 (tiga) dosis aktivator EM4 yang berbeda.

Metode penelitian adalah eksperimen murni dengan menggunakan desain penelitian Rancangan "Post Only With Control Grup". Sampel menggunakan Purposive random sampling berupa isi rumen sapi. Selanjutnya uji dilakukan dengan 4 perlakuan setiap 1 perlakuan 6 replikasi.

Berdasarkan pemeriksaan laboratorium pada gas metan $\left(\mathrm{CH}_{4}\right)$ dapat diketahui bahwa kadar gas metan $\left(\mathrm{CH}_{4}\right)$ yang tidak diberi penambahan aktivator EM4 sebesar 0,47950 dan penambahan aktivator EM4 yang efektif yaitu variasi dosis $20 \%$ sebesar 3,33103, penambahan dosis aktivator EM4 15\% sebesar 2,55065 dan penambahan dosis aktivator EM4 $10 \%$ sebesar 1,68862. Terdapat perbedaan kadar gas metan dengan variasi aktivator EM4 10\%, 15\%, dan 20\% pada proses bioga dengan menggunakan isi rumen sapi.

Penelitian ini dapat digunakan masyarakat sebagai bahan bakar alternatif untuk kegiatan sehari-hari. Penlitian ini juga dapat dilanjutkan dengan mengukur kadar gas metan total pada proses biogas.
\end{abstract}

Kata kunci: Biogas, Isi Rumen Sapi

\section{PENDAHULUAN}

Energi sudah menjadi kebutuhan pokok masyarakat Indonesia pada saat ini. Tingginya penggunaan energi di Indonesia dipengaruhi oleh meningkatnya pertumbuhan penduduk dan meningkatnya perkembangan industri. Pasokan untuk mendapatkan energi saat ini masih didominasi oleh sumber energi fosil yang tidak dapat diperbaharui yaitu minyak bumi, batu bara, dan gas alam. Besarnya penggunaan minyak sebagai sumber energi didominasi oleh transportasi, industri dan pembangkit daya atau listrik. Penggunaan minyak sebagai sumber energi menimbulkan persoalan serius pada lingkungan berkaitan dengan emisi gas rumah kaca, terutama $\mathrm{CO}_{2}$, yang merupakan penyebab terjadinya pemanasan global (Haryanto, 2014). Maka dibutuhkan energi alternatif yang ramah lingkungan dan memiliki sumber yang dapat diperharui.

Biogas merupakan salah satu alternatif sumber energi terbarukan yang dapat menjawab kebutuhan energi. Biogas adalah gas yang dihasilkan dari proses penguraian bahan-bahan oraganik oleh mikrooganisme dalam keadaan anaerob. Biogas mempunyai beberapa keuggulan dibandingkan dengan BBM yang berasal dari fosil. Sifatya yang ramah lingkungan dan dapat diperbaharui merupakan keunggulan dari biogas dibandingkan degan bakar fosil (Wahyuni, 2015).

Bahan dasar biogas dapat berasal dari limbah pertanian, kotoran hewan dan manusia, serta limbah organik lainnya (Abdulkareem, A.S. 2005). Bahan lain yang dapat digunakan dalam menghasilkan biogas adalah cairan isi rumen dan kotoran sapi, dimana cairan 
isi rumen dan kotoran sapi masih mengandung bahan organik yang tinggi. Limbah cairan isi rumen dan kotoran sapi banyak dihasilkan oleh Rumah Potong Hewan (RPH) sebagai produk samping yang dapat dimanfaatkan dalam menghasilkan biogas (Manendar, 2010).

Salah satu Rumah Potong Hewan (RPH) terbesar di Kota Surabaya adalah RPH Pegirian. RPH ini mampu memotong 150 ekor sapi dan 40 ekor kambing setiap harinya, serta 30 ekor babi setiap dua hari. Limbah padat RPH yang dihasilkan dari proses pemotongan terdiri atas rumen ( 0,38 ton), kotoran sapi dan rumput sisa pakan (5,26 ton). Limbah padat RPH tersebut belum dilakukan pengelolaan, biasanya ditumpuk di tempat terbuka dan ada pula yang langsung dibuang ke Tempat Pembuangan Akhir (TPA). Hal tersebut memberikan dampak negatif berupa pencemaran air permukaan, air tanah, tanah dan udara (Ratnawati, 2014). Sedangkan limbah cairan isi rumen masuk dalam Instalasi Pengolahan Air Limbah (IPAL) RPH namun belum dimanfaatkan sebagai biogas.

Rumen adalah salah satu bagian lambung ternak ruminansia atau hewan memamah biak seperti sapi, kerbau, kambing dan domba. Rumen terdiri dari bahan pakan yang biasanya dimakan oleh ternak yang berupa rumput/hijauan lainnya, dan pakan penguat (konsentrat). Produksi isi rumen sapi di Indonesia pada tahun 2012 mencapai 240 juta liter, karena baunya kuat dan kandungan air yang tinggi sehingga sulit penanganannya, selain itu hasil pencernaan hewan rumenisasi juga menghasilkan gas metana (Berutu, 2007).

Pengolahan limbah cairan isi rumen dan kotoran sapi dapat dilakukan dengan cara fermentasi anaerob (tanpa oksigen), dan merupakan salah satu alternatif untuk mengurangi pencemaran lingkungan. Dalam proses tersebut bahan organik akan didegrasi oleh mikroba yang dapat menghasilkan biogas. Carian rumen sapi dari limbah rumah potong hewan dapat dimafaatkan sebagai biostarter untuk mempercepat proses fermentasi kotoran untuk menghasilkan dan meningkatkan produksi gas metan dalam biogas (Susilowati, 2009).

Salah satu parameter yang mempengaruhi proses produksi biogas adalah tingkat pengenceran dan kandungan bahan organik di dalam biodigester. Pengenceran slurry di dalam biodigester berakibat pada turunnya Volatile Solid (VS) dan Total Solid (TS). Penurunan kadar Volatile Solid (VS) dan Total Solid (TS) berindikasi dengan peningkatan kadar gas metana yang dihasilkan.

Yulistiawati (2008), mengemukakan bahwa peningkatan produksi biogas pada awal proses fermentasi disebabkan karena pada tahap awal mikroba di dalam fermentor masih dalam keadaan segar seperti dalam rumen, sedangkan pada waktu berikutnya zat nutrisi yang tersedia jumlahnya semakin berkurang.

\section{METODE PENELITIAN Jenis Penelitian}

Penelitian ini tergolong eksperimen murni dengan menggunakan desain penelitian Rancangan "Post Only With Control Grup" dilakukan dengan cara pengukuran produksi biogas, mengisolasi dan mengamati ciri morfologi bakteri anaerob dari campuran limbah isi rumen sapi yang diberi tambahan ragi. Desain penelitian ini dapat digambarkan seperti berikut ini.

\begin{tabular}{lll} 
Subjek & Perlakuan & posttest \\
\hline $\begin{array}{l}\text { Kelompok } \\
\text { Eksperimen }\end{array}$ & $\mathrm{X}$ & $\mathrm{O}_{2}$ \\
\hline $\begin{array}{l}\text { Kelompok } \\
\text { Kontrol }\end{array}$ & $\mathrm{O}_{4}$
\end{tabular}

Keterangan:

perlakuan : pembuatan biogas dengan perbandingan antara air, isi rumen sapi dan EM4 sebagai berikut $10 \%, 15 \%$, $20 \%$

Posttest : pengukuran kadar ga metana setelah dilakukan pembuatan biogas

\section{Desain Penelitian}




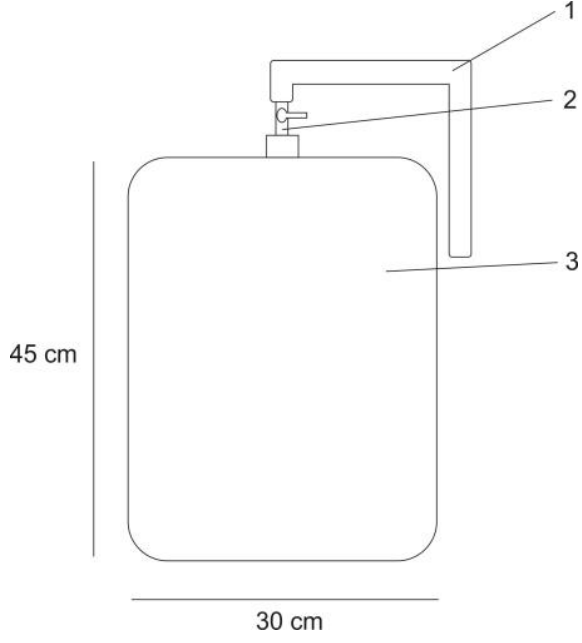

Keterangan :

1. Selang $5 / 8$ inchi

2. Kran Gas $3 / 8$ inchi

3. Bak Penampung Bahan

Objek penelitian ini yaitu perbedaan kandungan gas metana pada biogas dengan variasi kadar campuran pembuatan biogas dengan perbandingan antara air, isi rumen sapi, dan EM4 sebagai berikut $10 \%, 15 \%$ dan $20 \%$.

Sampel pada penelitian ini diambil dengan menggunakan teknik purposive random sampling. Purposive random sampling merupakan teknik pengambilan sampel yang didasarkan pertimbangan tertentu yang dibuat oleh peneliti (Notoatmodjo, 2010). Sampel pada penelitian ini adalah rumen sapi yang jumlahnya dihitung menggunakan rumus Federer sebagai berikut.

$$
\begin{aligned}
& (t-1) \times(r-1) \geq 15 \\
& r=\text { jumlah replikasi } \\
& t=\text { jumlah perlakuan }
\end{aligned}
$$

Dalam penelitian ini terdapat 4 perlakuan P0 (P1, P2, P3), maka jumlah replikasinya yaitu :

$$
(4-1) \times(r-1) \geq 15
$$

$$
\begin{aligned}
& 3(r-1) \quad \geq 15 \\
& 3 \mathrm{r}-3 \geq \geq 15 \\
& 3 r \quad \geq 15+3 \\
& 3 r \quad \geq 18 \\
& r \quad \geq 6
\end{aligned}
$$

Berdasarkan hasil perhitungan di atas, didapatkan hasil 6 replikasi untuk satu perlakuan. Jumlah sampel penelitian didapatkan dari jumlah replikasi dikali jumlah perlakuan ditambah kontrol, yaitu $6 \times 4=24$ sampel.

\section{Variabel yang diteliti}

Variabel bebas dalam penelitian ini adalah EM4 yang digunakan sebagai aktifator. $10 \%, 15 \%$ dan $20 \%$. Varibael terikat dalam penelitian ini ada limbah cairan isi rumen sapi. Variabel kontrol dalam penelitian yaitu waktu dan komposisi bahan isi rumen dan air.

Analisis data yang digunakan yaitu analisis analitik dan deskriptif. Data yang dianalisis yaitu hasil pemeriksaan laboratorium mengenai kadar gas metana pada limbah isi rumen sapi sebelum dan sesudah pengolahan dengan biogas. Dalam analisis analitik, peneliti menggunakan uji statistik Anova Satu Arah (One Way Anova) jika data berdistribusi normal, dan menggunakan uji Kruskal Wallis apabila data tidak berdistribusi normal. Uji statistik tersebut bertujuan untuk mengetahui apakah terdapat perbedaan penurunan kadar gas metana pada limbah isi rumen sapi dari 3 perlakuan yang diberikan.

Apabila pada uji perbedaan didapatkan hasil yaitu terdapat perbedaan kadar gas metan dari setiap perlakuan yang diberikan saat pembuatan biogas, maka perlu dilakukan uji lanjutan yaitu menggunakan uji LSD (Least Square Differences) yang bertujuan untuk mengetahui pemberian EM4 yang paling optimum untuk meningkatkan kadar gas metana pada limbah isi rumen sapi. 
HASIL DAN PEMBAHASAN

\section{Tabel 1}

KADAR GAS METAN

\begin{tabular}{|c|c|c|c|c|c|}
\hline \multirow{2}{*}{ No } & \multirow{2}{*}{ Parameter } & \multicolumn{4}{|c|}{ Perlakuan Penambahan Aktivator EM4 } \\
\hline & & $0 \%$ & $10 \%$ & $15 \%$ & $20 \%$ \\
\hline 1 & \multirow{6}{*}{ Gas Metan } & 0,47584 & 1,68340 & 2,54287 & 3,32960 \\
\hline 2 & & 0,48189 & 1,68492 & 2,54682 & 3,32781 \\
\hline 3 & & 0,47327 & 1,69720 & 2,56395 & 3,33290 \\
\hline 4 & & 0,48478 & 1,68938 & 2,54751 & 3,33850 \\
\hline 5 & & 0,48295 & 1,68395 & 2,55487 & 3,32581 \\
\hline 6 & & 0,47832 & 1,69288 & 2,54790 & 3,33158 \\
\hline Rat & & 0,47950 & 1,68862 & 2,55065 & 3,33103 \\
\hline
\end{tabular}

Berdasarkan hasil yang diperoleh pada tabel 1 dapat diketahui bahwa Rata-rata kadar gas metan $\left(\mathrm{CH}_{4}\right)$ pada proses biogas yang diberi aktivator EM4 berdasarkan variasi dosis $10 \%, 15 \%$ dan $20 \%$ berturut-turut sebesar 1,68862 , 2,55065, dan 3,33103, jadi variasi dosis aktivator EM4 yang efektif yaitu variasi dosis $20 \mathrm{ml}$ sebesar 3,33103.

Berdasarkan hasil uji One Way Anova diperoleh nilai $\rho$ sebesar 0,00 yang artinya $\rho<0,05$ (a ) maka terdapat pengaruh yang significant sehingga terjadi peningkatan gas metan $\left(\mathrm{CH}_{4}\right)$ pada proses biogas dengan penambahan aktivator EM4. untuk mengetahui perbedaan rata-rata setiap perlakuan terhadap kadar gas metan $\left(\mathrm{CH}_{4}\right)$ maka harus dilakukan uji lanjutan (Post Hoc Test). Berdasarkan uji lanjutan menggunakan uji LSD (Least Significance Different) diperoleh perbedaan rata-rata perlakuan dosis $10 \%$ dengan dosis $0 \%$ sebesar 1,2 , dosis $15 \%$ dengan dosis $0 \%$ sebesar 2,07 , dosis $15 \%$ dengan dosis $10 \%$ sebesar 0,86 , dosis $20 \%$ dengan dosis $0 \%$ sebesar 2,85 , dosis $20 \%$ dengan dosis $10 \%$ sebesar 1,64 , dan dosis $20 \%$ dengan $15 \%$ sebesar 0,78 . Dari hasil tersebut maka dapat diketahui bahwa perbedaan rata-rata kadar gas metan $\left(\mathrm{CH}_{4}\right)$ signifikan terjadi pada perlakuan dosis $20 \%$ dengan dosis $0 \%$ yaitu sebesar 2,85.

\section{KESIMPULAN}

1. Rata-rata kadar gas metan $\left(\mathrm{CH}_{4}\right)$ pada proses biogas yang diberi aktivator EM4 berdasarkan variasi dosis $10 \%$, $15 \%$ dan $20 \%$ berturut-turut sebesar 1,68862, 2,55065, dan 3,33103, jadi variasi dosis aktivator EM4 yang efektif yaitu variasi dosis $20 \mathrm{ml}$ sebesar 3,33103.

2. Terdapat pengaruh yang signifikan setelah dilakukan penambahan aktivator EM4 dengan variari dosis $10 \%, 15 \%$ dan $20 \%$ terhadap peningkatan kadar gas metan $\left(\mathrm{CH}_{4}\right)$ pada proses biogas menggunakan isi rumen.

\section{SARAN}

1. Bagi Pihak RPH

a. Isi rumen sapi dapat dimanfaatkan sebagai bahan bakar alternatif untuk mengurangi penyebab pencemaran lingkungan.

b. Perlu adanya sosialisasi tentang pemanfaatan pengolahan isi rumen sapi.

2. Bagi Peneliti Lain

a. Perlu diadakan penelitian lebih lanjut untuk variasi waktu dan varisi substrat yang berbeda.

b. Perlu diadakan penelitian lebih lanjut dengan menghitung 
jumlah total gas metan pada penambahan EM4

\section{DAFTAR PUSTAKA}

Abudulkareem, A.S. 2005. Refining Biogas Produced from Biomass: An Alternative to Cooking Gas. Chemical Engineering Department, Federal University of Technology, Minna, Niger state, Nigeria Leonardo Jpurnal of Sciences, Issue 7, p. 1-8, July-Desember 2005.

Berutu, K.M., 2007. Dampak Lama Transportasi

TerhadapPenyusutan Bobot Badan, pH Daging Pasca Potong dan Analisis Biaya Transportasi Sapi Potong Peranakan Ongole dan Shorthorn. Skripsi pada Departemen Peternakan Fakultas Pertanian USU.

Haryanto, A. 2014. Energi Terbarukan. Bandar Lampung. Bab V : 195 - 246.

Manendar. R. 2010. Pengolahan Limbah Cair Rumah Pemotongan Hewan (RPH) Dengan Metode Fotokalitik TiO2
: Pengaruh Waktu Kontak Terhadap Kualitas BOD5, COD, dan $\mathrm{pH}$ Efluen. Tesis. Program Studi Kesehatan Masyarakat Veteriner Sekolah Pascasarjana Institut Pertanian Bogor. Bogor.

Ratnawati. R, Wulandari, dan Nurul. Pengolahan Limbah Padat Rumah Potong Hewan dengan Metode Pengomposan Aerobik dan Anaerobik. Universitas Brawijaya Malang.

Susilowati, E. (2009). Uji pemanfaatan Cairan Rumen Sapi untuk Meningkatkan Kecepatan Produksi Biogas dan Konsentrasi Gas Metan dalam Biogas. Thesis. Universitas Gajah Mada.

Wahyuni, S. 2015. Panduan Praktis Biogas. Penebar Swadaya. Jakarta Timur. $116 \mathrm{hlm}$.

Yulistiawati. E. 2008. Pengaruh Suhu dan C/N Rasio Terhadap Produksi Biogas Berbahan Baku Sampah Organik Sayuran. Skripsi. Program Strata I Institut Pertanian Bogor. Bogor. 